\title{
Rigid Covalent Atomic Groups in Precrystallization Phase for Hg-containing Compounds
}

\author{
Victor V. Atuchin, Stanislav V. Borisov, Svetlana A. Magarill, and Natalia V. Pervulhina
}

\begin{abstract}
During crystal chemical analysis of about fifty mercury-containing compounds the atomic groups same from structure to structure were found. Such atomic groups, namely $\left[\mathrm{Hg}_{4} \mathrm{O}\right]$ oxo-centered tetrahedron and $\mathrm{r}$-octahedron $\left[\mathrm{Hg}_{6} \mathrm{O}_{2}\right]$, are covalently bonded. Quantum-chemical calculations prove stability of these 'rigid' atomic groups that are assumed to be formed in the beginning of crystallization. Thus, mechanism of crystallization proposed includes mutual arrangement of isolated or joint-like linked rigid atomic groups and finally their regular packing. At that point symmetry of these rigid atomic groups becomes subgroup of space group of the whole structure.
\end{abstract}

Index Terms-Crystal structure, mercury, minerals, coordination.

\section{INTRODUCTION}

Mercury compounds are key materials for many applications in micro- and nanoelectronics, photonics and nonlinear optics [1-7]. Because of chemical activity and oxidation state variability of mercury ions in nature many complex mercury-containing minerals are found in the earth-crust [8-12]. Understanding of crystal chemistry of mercury-bearing minerals and release ways for the hazardous components are of great importance for the environment keeping. Several new mercury-containing crystals have been discovered over recent years in the oxide and halcogenide systems that greatly extends the spectrum of effective materials for different applications [13-21].

Generally, mercury oxides, oxo- and chalcohalides are known to have intrigueing, complex and multifarious structural and crystal chemistry. Mercury atoms can be bonded to oxygen, chalcogen, halogen or some other atoms both in covalent or ionic manner, be bonded to metal atoms to form mono- $\left(\left[\mathrm{Hg}_{2}\right]^{2+}\right.$ dumbbells, $\left[\mathrm{Hg}_{3}\right]^{4+}$ triangles etc.) and hetero-nuclear clusters with silver, lead and several other metal atoms [22,23]. The crystal chemistry of mercury-containing compounds is of additional interest owing to ecological reasons concerning the occurrence of these compounds in the earth's crust, water and atmosphere.

Manuscript received May 25, 2011. This work was supported in part by the Russian Foundation for Basic Research under Grant 04-05-64058 and Siberian Branch of Russian Academy of Science under Grant 34 (2011).

V. V. Atuchin is with the Laboratory of Optical Materials and Structures, Institute of Semiconductor Physics, SB RAS, Novosibirsk, 630090, Russia (e-mail: atuchin@thermo.isp.nsc.ru).

S. V. Borisov, S. A. Magarill, and N. V. Pervukhina are with the Laboratory of Crystal Chemistry, Institute of Inorganic Chemistry, SB RAS, Novosibirsk, 630090, Russia (e-mail: borisov@niic.nsc.ru, svetlana@niic.nsc.ru, pervukh@niic.nsc.ru).

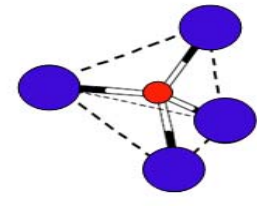

a

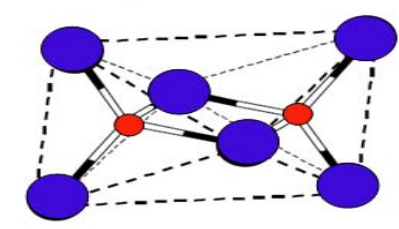

b

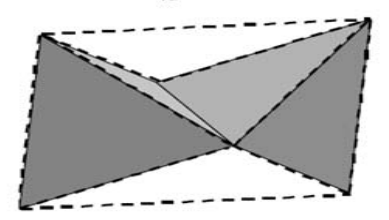

c

Fig. 1.Undistorted (a) $\left[\mathrm{Hg}_{4} \mathrm{O}\right]$ cationic tetrahedron and (b) $\left[\mathrm{Hg}_{6} \mathrm{O}_{2}\right]$ $r$-octahedron, i.e. a pair of $\left[\mathrm{Hg}_{4} \mathrm{O}\right]$ cationic tetrahedra, sharing an edge (c). Dashed lines show convex shape of the atomic groups.

Some features of crystal chemistry for compounds containing divalent mercury, oxygen, chalcogen and halogen atoms were investigated earlier and structural principles of formation for these compounds were proposed. It was shown that linear $\mathrm{Y}-\mathrm{Hg}-\mathrm{Y}$ groups, where $\mathrm{Y}$ are $\mathrm{O}, \mathrm{N}, \mathrm{S}$, Se or Te atoms, are typical building blocks in crystal structures of most compounds. The groups are usually characterized by a $\mathrm{YHgY}$ bond angle of about $180^{\circ}$ and shortened contact $\mathrm{Hg}-\mathrm{Y}$, e.g., $\mathrm{Hg}-\mathrm{O}$ and $\mathrm{Hg}-\mathrm{S}$ average distances are of 204 and 234 pm, respectively. Present study is aimed to continue this analysis with accounting new mercury-containing crystals and reveal some specific structural features general for this chemical class.

\section{HG-CONTAINING COMPOUNDS}

During crystallochemical analysis of about fifty Hg-containing compounds so-called 'rigid' atomic groups were found by detailed observation of coordination of metal atoms by anions. These atomic groups are called 'rigid' owing to their interatomic distances and bond angles remaining practically unchanged over a number of structures. Chemical bonding in such groups is usually partly or totally covalent with comparatively short bond lengths. If in the crystal structure there are oxygen atoms, which do not comprise anions such as $\left[\mathrm{PO}_{4}\right]^{3-},\left[\mathrm{SO}_{4}\right]^{2-},\left[\mathrm{SiO}_{4}\right]^{4-}$ etc., they usually form $\left[\mathrm{Hg}_{4} \mathrm{O}\right]$ cationic tetrahedra (Fig. 1) with $\mathrm{Hg}-\mathrm{Hg}$ 
and $\mathrm{Hg}-\mathrm{O}$

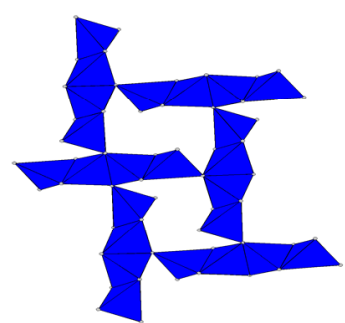

Fig. 2.Fragment of layer of doubled r-octahedra in $\beta-\mathrm{Hg} 6 \mathrm{O} 4 \mathrm{Cl} 4$ crystal structure.

distances of 350 and $190-278 \mathrm{pm}$ respectively [22-26]. In crystal structures of oxohalides such as $\mathrm{Hg}_{6} \mathrm{O}_{2} \mathrm{Cl}_{2}$, $\alpha-\mathrm{Hg}_{3} \mathrm{O}_{2} \mathrm{Cl}_{2}, \mathrm{Hg}_{2} \mathrm{OI}, \mathrm{Hg}_{7} \mathrm{O}_{3} \mathrm{Cl}_{2}$ etc., the 2 cationic tetrahedra share edges to form so-called 'r-octahedron' $\left[\mathrm{Hg}_{6} \mathrm{O}_{2}\right]$ (Fig. 1b, c), or a pair of r-octahedra like in $\beta-\mathrm{Hg}_{3} \mathrm{O}_{2} \mathrm{Cl}_{2}$ or $\mathrm{Hg}_{6} \mathrm{O}_{4} \mathrm{Cl}_{4}$ [25] (Fig. 2). Centroids of r-octahedra usually coincide with symmetry centers. Thus, crystal structure may be described as
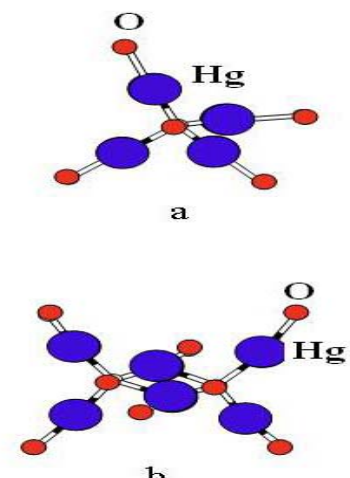

b

Fig. 3.Atomic groups (a) [Hg4O5]2- and (b) [Hg6O8]4- are chosen for quantum-chemical calculations.

regular close packing of such rigid atomic groups. The rest atoms occupy the voids of the packing. To prove that the $\left[\mathrm{Hg}_{4} \mathrm{O}\right]$ cationic tetrahedra and $\left[\mathrm{Hg}_{6} \mathrm{O}_{2}\right]$ r-octahedra are reasonable to be chosen as structure-forming groups the quantum-chemical calculations of model systems $\left[\mathrm{Hg}_{4} \mathrm{O}_{5}\right]^{2-}$ and $\left[\mathrm{Hg}_{6} \mathrm{O}_{8}\right]^{4-}$ were performed that are cationic tetrahedron and $r$-octahedron respectively with nearest covalent environment of mercury atoms (Fig. 3a,b). For calculations ZORA method [27] implemented in ADF program package [28] was used. The calculations show that $\left[\mathrm{Hg}_{6} \mathrm{O}_{8}\right]^{4-}$ group is energetically more stable than single $\left[\mathrm{Hg}_{4} \mathrm{O}_{5}\right]^{2-}$ group [29]. From geometrical point of view similar highly stable atomic groups containing metal-metal bonds were found in the various types of compounds. An 'unprecedented stability' of $\left[\mathrm{Au}_{4} \mathrm{OP}_{4}\right]$ oxo-centered tetrahedron with covalent contacts of $\mathrm{Au}-\mathrm{Au}=335.9 \mathrm{pm}, \mathrm{Au}-\mathrm{O}=205.7 \mathrm{pm}, \mathrm{Au}-\mathrm{P}=222.5$ pm etc. was reported for $\mathrm{C}_{84} \mathrm{H}_{84} \mathrm{Au}_{4} \mathrm{~B}_{2} \mathrm{~F}_{8} \mathrm{OP}_{4}$ crystal structure [30]. Stable $\left[\mathrm{Au}_{4} \mathrm{Rh}_{2} \mathrm{O}_{2}\right]$ r-octahedron, with interatomic distances $\mathrm{Au}-\mathrm{Au}=300.8 \mathrm{pm}, \mathrm{Au}-\mathrm{Rh}=298.4$ and $302.0 \mathrm{pm}, \mathrm{Au}-\mathrm{O}=$ 202.6 and $208.3 \mathrm{pm}, \mathrm{Rh}-\mathrm{O}=209.5$ and $211.8 \mathrm{pm}$ is found for $\left[\left\{(\text { dien }) \mathrm{Rh}\left[\mu-\mathrm{O}\left(\mathrm{AuPPh}_{3}\right)_{2}\right]\right\}_{2}\right]\left[\mathrm{BF}_{4}\right]$ [31]. Let us consider crystal structure of $\mathrm{AgHg}_{2} \mathrm{PO}_{4}$ [32], which is an example of unusual combination of cationic and anionic groups. Cationic
$\left[\mathrm{Hg}_{4} \mathrm{Ag}_{2}\right] \mathrm{r}$-octahedra consist of a pair of $\left[\mathrm{Hg}_{2} \mathrm{Ag}_{2}\right]$ tetrahedra sharing Ag-Ag edge. Symmetry center is in the center of the Ag-Ag edge that coincides with the centroid of r-octahedron. In contrast to above-mentioned structures there is no oxygen atom in the center of the tetrahedron, and the tetrahedron is rather smaller $(\mathrm{Hg}-\mathrm{Hg}=260.8 \mathrm{pm} ; \mathrm{Ag}-\mathrm{Ag}=282.4 \mathrm{pm}$; $\mathrm{Hg}-\mathrm{Ag}=284.0,294,1 \mathrm{pm})$. Anionic fragment is a pair of $\left[\mathrm{PO}_{4}\right]$ tetrahedra related by symmetry center so that an empty octahedron of oxygen atoms separates them from each other (Fig. 4). Centroids of the complex anions and cluster cations are packed according to pseudo-BCC lattice.

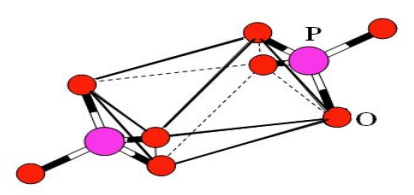

Fig. 4.An anionic part 2[PO4] of AgHg2PO4 crystal structure. Two [PO4]-groups that are trans to each other form an empty 'O6 octahedron' (thin lines).

Recently tetragonal structure of tillmansite $\left[\mathrm{Ag}_{3} \mathrm{Hg}\right]\left[(\mathrm{V}, \mathrm{As}) \mathrm{O}_{4}\right]$ was solved [33]. A mercury and three silver atoms statistically occupy vertices of each $\left[\mathrm{Ag}_{3} \mathrm{Hg}\right]$ cationic tetrahedron, which is also empty. Cation-cation distances are 275.2 and $273.8 \mathrm{pm}$. The tetrahedral anions $\left[(\mathrm{V}, \mathrm{As}) \mathrm{O}_{4}\right]$ are interlaid with empty ' $\mathrm{O}_{4}$ tetrahedra'. Both $\left[(\mathrm{V}, \mathrm{As}) \mathrm{O}_{4}\right]$ anions and $\mathrm{O}_{4}$ tetrahedra share edges to form chain going along z-axis (Fig. 5). In the centers of both tetrahedra there are -4 special positions of $I-4$ space group. The rest two -4 special positions are in the centers of aforementioned empty cationic tetrahedron and also empty $\left[\mathrm{Ag}_{3} \mathrm{Hg}\right]$ tetrahedron. The latter tetrahedron is elongated along z-axis. Its edges of about 33.5 A tilted to ab-plane are an evidence of no strong chemical interactions between the metal atoms. Both tetrahedra share edges and are arranged in alternative order. Like in the $\mathrm{AgHg}_{2} \mathrm{PO}_{4}$ structure each pair of cationic tetrahedra may be considered as distorted 'empty' r-octahedron. In crystal structure the tapes of r-octahedra and tapes of anionic tetrahedra are interleaved in chess-like order as can be clearly seen in Fig. 5. Note that positions of the cations $(\mathrm{Ag}, \mathrm{Hg})$ and $(\mathrm{V}, \mathrm{As})$ form pseudo-FCC lattice. Sub-unit of the lattice is $2 / 5$ times smaller than original tetragonal asymmetric unit.

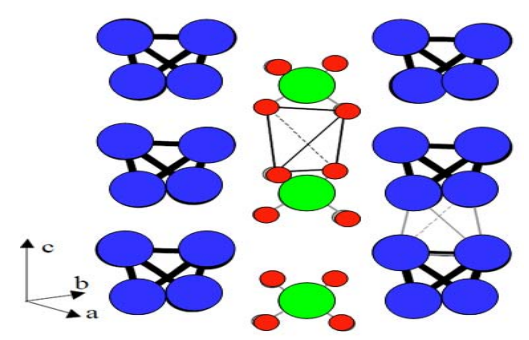

Fig. 5.Tillmansite $(\mathrm{Ag} 3 \mathrm{Hg})(\mathrm{V}, \mathrm{As}) \mathrm{O} 4$ crystal structure. Chess-like packing of $[\mathrm{Ag} 3 \mathrm{Hg}]$ and $[(\mathrm{V}, \mathrm{As}) \mathrm{O} 4]$ tapes. Red, dart blue and green circles denote $\mathrm{O}$, $\mathrm{Ag}$ and $\mathrm{Hg}$, As and $\mathrm{V}$ atoms respectively.

We suppose that such rigid atomic groups, as $r$-octahedra are likely to exist even before crystallization if there are appropriate mercury and oxygen stoichiometric relationships, proper charge compensation components etc. This is 
naturally because the forces that cause formation of rigid atomic groups are much stronger than the forces, responsible for crystallization or, other words, long-range order arrangement of atoms or centroids of the rigid atomic groups. Thus, the mechanism of the crystallization was proposed in Ref. [34], according to which mutual joint-like movement of nearest rigid atomic groups around the bonds between them yields to regular close packing (Fig. 2,6). Centroids of the rigid atomic groups are fixed on crystallographic planes, which $d h k l$ are close to linear dimensions of the groups. We think that the arrangement of these groups gives main contribution to crystallization process just like in case of molecular compounds. Moreover, own point symmetry of rigid atomic groups should predetermine someway the symmetry of a crystal structure, because these groups usually occupy highsymmetry special positions as one can see from the aforementioned examples.

\section{CONCLUSION}

Thus, the formation of mercury-containing crystal structures may be assumed to be the result of primarily the low-resolution (large $d_{\mathrm{hkl}}$ ) ordering of the building blocks, the largest in size and mass, by a set of unique crystallographic planes or, in other words, by coordinate planes that form a translation-related sublattice of the building blocks $[22,23,25,34]$. At the same time, the coordinate planes of unique sublattices can arrange smaller building blocks and single atoms giving high-resolution ordering (smaller $d_{\mathrm{hkl}}$ ). Some atoms of the large building blocks may also take part in the ordering of small building blocks. When the crystal structure has been formed, all sets of primarily unique sublattices of different combinations of atoms and rigid atomic groups have formed a general periodic lattice, which fits to all atoms and rigid atomic groups. The unit cell of the lattice includes an integer number of any subcell, while indices of all sets of planes are integers. Thus, all sets of planes become crystallographic.

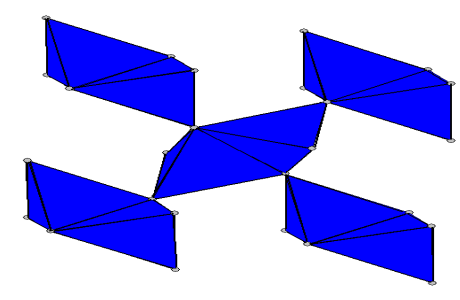

Fig. 6.Herringbone packing pattern of joint-like fitting r-octahedra along yz-plane in $-\mathrm{Hg} 3 \mathrm{O} 2 \mathrm{Cl} 2$ crystal structure.

The stability of a crystal structure is known to depend on decreasing the degrees of freedom of the atoms in comparison with the initial chaotic arrangement. Another way to decrease degrees of freedom and, therefore, to minimize the energy of an atomic ensemble is in the symmetry relations between the ordering planes. This is the reason for atoms to occupy the special positions in a crystal structure and, thus, to stabilize it. The local point symmetry of a building block influences the space symmetry of a crystal structure as has been illustrated above.

\section{REFERENCES}

[1] Chunxia Wang, Jürgen Roither, Raimund Kirschschlager, Maksym V. Kovalenko, Moritz Brehm, Thomas Fromherz, Qiang Kan, Pingheng Tan, Jian Liu, Hongda Chen, and Wolfgang Heiss, "Enchanced infrared emission from colloidal $\mathrm{HgTe}$ nanocrystal quantum dots on silicon-on-insulator photonic crystals," Appl. Phys. Lett., vol. 95, pp. 053107, 2009.

[2] M. Cardona, R. K. Kremer, R. Lauck, G. Siegle, A. Munoz, A. H. Romero, "Electronic, vibrational, and thermodynamic properties of metacinnabar $\beta$-HgS, HgSe, and HgTe," Phys. Rev. B, vol. 80, pp. 195204, 2009 .

[3] Jun Wang, Xiaoshuang Chen, Ziqian Wang, Weida $\mathrm{Hu}$, Wei Lu, Faqiang Xu, "The mechanism of the photoresponse blueshifts for the n-type conversion region of $n^{+}$-on- $p \quad \mathrm{Hg}_{0.722} \mathrm{Cd}_{0.278} \mathrm{Te}$ infrared photodiode," J. Appl. Phys., vol. 107, pp. 044513, 2010.

[4] V. V. Atuchin, S. V. Borisov, S. A. Magarill, and N. V. Pervukhina, "Crystal structural premises on epitaxial contacts for a series of mercury-containing compounds," J. Cryst. Growth, vol. 318, pp. 1125-1128, 2011.

[5] J. Mangin, G. Mennerat, G. Gadret, V. Badikov, J. C. de Miscault, "Comprehensive formulation of temperature-dependent dispersion of optical materials: illustration with case of temperature tuning of a mid-IR $\mathrm{HgGa}_{2} \mathrm{~S}_{4}$ OPO," J. Opt. Soc. Am. B, vol. 26, pp. 1702-1709, 2009.

[6] Tie-Jun Wang, Zhi-Hui Kang, Hong-Zhi Zhang, Zhi-Shu Feng, Feng-Guang Wu, Hai-Yan Zang, Yun Jiang, Jin-Yue Gao, Yury Andreev, Grigory Lanskii, Victor Atuchin, Oleg Parasyuk, "Sellmeier equations for green, yellow, and orange coloured $\mathrm{HgGa}_{2} \mathrm{~S}_{4}$ crystals," Appl. Phys. Lett., vol. 90, pp. 181913, 2007.

[7] V. V. Atuchin, V. G. Kesler, V. V. Ursaki, V. E. Tezlevan, "Electronic structure of $\mathrm{HgGa}_{2} \mathrm{~S}_{4}$," Solid State Commun., vol. 138, pp. 250-254, 2006.

[8] N. V. Pervukhina, S. V. Borisov, S. A. Magarill, D. Y. Naumov, V. I. Vasil'evz, "The crystal structure of kelyanite, $\left(\mathrm{Hg}_{2}\right)_{6}\left(\mathrm{SbO}_{6}\right) \mathrm{BrCl}_{2}$, " $A m$. Miner., vol. 93, pp. 1666-1669, 2008

[9] N. V. Pervukhina, S. V. Borisov, S. A. Magarill, V. I. Vasilev, N. V. Kuratieva, "Redetermination and crystallographic analysis of the structure of $\mathrm{Sb}$-containing laffittite $\mathrm{AgHg}(\mathrm{As}, \mathrm{Sb}) \mathrm{S}_{3}$ from Chauvai (Kyrgyzstan)," J. Struct. Chem., vol. 51, pp. 683-688, 2010.

[10] N. V. Pervukhina, S. V. Borisov, S. A. Magarill, V. I. Vasuliev, N. V. Kuratieva, S. G. Kozlova, "Refinement of the crystal structure of As-schwartzite $\mathrm{Cu}_{6}\left(\mathrm{Cu}_{5.26} \mathrm{Hg}_{0.75}\right)\left(\mathrm{As}_{2.83} \mathrm{Sb}_{1.17}\right) \mathrm{S}_{13} \quad$ (Aktash, Altai mountaines)," J. Struct. Chem., vol. 51. pp. 898-903, 2010.

[11] V. I. Vasil'ev, N. V. Pervukhina, S. V. Borisov, S. A. Magarill, "New data on the composition and crystal structure of galkhaite $(\mathrm{Hg}, \mathrm{Cu})_{6}(\mathrm{CsTl})(\mathrm{As}, \mathrm{Sb})_{4} \mathrm{~S}_{12}, "$ Geology Ore Deposits, vol. 52, pp. $662-668,2010$.

[12] V. I. Vasil'ev, N. V. Pervukhina, S. V. Borisov, S. A. Magarill, D. Y Naumov, N. V. Kurat'eva, "Aktashite $\mathrm{Cu}_{6} \mathrm{Hg}_{3} \mathrm{As}_{4} \mathrm{~S}_{12}$ from the Aktash Deposit, Altai, Russia: Refinement and crystal chemical analysis of the structure," Geology Ore Deposits, vol. 52, pp. 656-661, 2010.

[13] O. V. Parasyuk, L. D. Gulay, L. V. Piskach, O. P. Gagalovska, "The $\mathrm{Ag}_{2} \mathrm{~S}-\mathrm{HgS}-\mathrm{GeS}_{2}$ system at $670 \mathrm{~K}$ and the crystal structure of the $\mathrm{Ag}_{2} \mathrm{HgGeS}_{4}$ compound," J. Alloys Compd., vol. 336, pp. 213-217, 2002.

[14] O. V. Parasyuk, L. D. Gulay, Ya. E. Romanyuk, I. D. Olekseyuk, L. V. Piskach, "The $\mathrm{Ag}_{2} \mathrm{Se}-\mathrm{HgSe}-\mathrm{GeSe}_{2}$ system and crystal structures of the compounds," J. Alloys Compd., vol. 351, pp. 135-144, 2003.

[15] O. V. Parasyuk, S. I. Chykhrij, V. V. Bozhko, L. V. Piskach, M. S. Bogdanyuk, I. D. Olekseyuk, L. V. Bulatetska, V. I. Pekhnyo, "Phase diagram of the $\mathrm{Ag}_{2} \mathrm{~S}-\mathrm{HgS}-\mathrm{SnS}_{2}$ system and single crystal preparation, crystal structure and properties of $\mathrm{Ag}_{2} \mathrm{HgSnS}_{4}$," J. Alloys Compd., vol. 399 , pp. 32-37, 2005.

[16] M. Weil, S. Baumann, D. K. Breitinger, " $\mathrm{K}_{2}\left[\mathrm{O}\left(\mathrm{HgSO}_{3}\right)_{3}\right]$, a new sulfito-mercurate with an $\left[\mathrm{OHg}_{3}\right]$ core," Acta Cryst. C, vol. 64, pp. $135-137,2008$

[17] Matthias Weil, Stefan Baumann, Dietrich K. Breitinger, "Structural studies of new sulfito mercurates(II) with general formula $x M\left[X \mathrm{HgSO}_{3}\right] \cdot y \mathrm{Hg} X_{2} \cdot z M \mathrm{X} \cdot n \mathrm{H}_{2} \mathrm{O}\left(M=\mathrm{NH}_{4}, \mathrm{~K} ; X=\mathrm{Cl}, \mathrm{Br}\right), "$ Z. Anorg. Allgem. Chem., vol. 634, pp. 1742-1748, 2008.

[18] Matthias Weil, Stefan Baumann, Dietrich K. Breitinger, “ $\mathrm{K}_{2}\left[\mathrm{Hg}\left(\mathrm{SO}_{3}\right)_{2}\right] \cdot 2.25 \mathrm{H}_{2} \mathrm{O}$," Acta Cryst. C, vol. 66, pp. I89-i91, 2010.

[19] V. R. Kozer, O. V. Parasyuk, I. D. Olekseyuk, "Phase equilibria in the systems $\mathrm{AgInSe} \mathrm{S}_{2}-\mathrm{HgIn}_{2} \mathrm{Se}_{4}$ and $\mathrm{AgInSe} \mathrm{e}_{2}-\mathrm{Hg}-\mathrm{Se}$," Inorg. Mater., vol. 46, pp. 609-613, 2010 
[20] V. R. Kozer, A. O. Fedorchuk, I. D. Olekseyuk, O. V. Parasyuk, "Crystal structure of the phases $\mathrm{Hg}_{5} \mathrm{C}^{\mathrm{III}} \mathrm{X}_{8}\left(\mathrm{C}^{\mathrm{III}}=\mathrm{Ga}\right.$, In; $\left.\mathrm{X}=\mathrm{Se}, \mathrm{Te}\right)$, , $J$. Alloys Compd., vol. 503, pp. 40-43, 2010.

[21] Jian-Ping Zou, Sheng-Lian Luo, Xing-Hua Tang, Ming-Jun Li, Ai-Qin Zhang, Qiang Peng, Guo-Cong Guo, "Synthesis, crystal and band structures, and optical properties of a new framework mercury pnictides: $\left[\mathrm{Hg}_{4} \mathrm{As}_{2}\right]\left(\mathrm{InBr}_{3.5} \mathrm{As}_{0.5}\right)$ with tridymite topology," J. Alloys Compd., vol. 509, pp. 221-225, 2011.

[22] N. V. Pervukhina, S. A. Magarill, S. V. Borisov, G. V. Romanenko, N. A. Palchik, "Crystal chemistry of compounds containing mercury in low oxidation states," Uspekhi Khimii, vol. 68, pp. 683-707, 1999.

[23] S. A. Magarill, N. V. Pervukhina, S. V. Borisov, N. A. Pal'chik, "Crystal chemistry and features of structure formation of mercury oxoand chalcohalides," Uspekhi Khimii, vol. 76, pp. 115-146, 2007.

[24] S. V. Krivovichev, S. K. Filatov, T. F. Semenova, "Types of cationic complexes based on oxo-centered tetrahedra $\left[\mathrm{OM}_{4}\right]$ in crystal structures of inorganic compounds," Uspekhi Khimii, vol. 67, pp. 155-174, 1998.

[25] S. A. Magarill, G. V. Romanenko, N. V. Pervukhina, S. V. Borisov, n. A. Polchik, "Oxocentered polycationic complexes - An alternative approach to crystal-chemical investigation of the structure of natural and synthetic mercury oxosalts," J. Struct. Chem., vol. 41, pp. 96-105, 2000.

[26] S. V. Borisov, "Crystalline state," J. Struct. Chem., vol. 33, pp. 871-877, 1992

[27] Erik van Lenthe, Andreas Ehlers, and Evert-Jan Baerends, "Geometry optimizations in the zero order regular approximation for relativistic effects," J. Chem. Phys., vol. 110, pp. 8943-8953, 1999.

[28] Amsterdam Density Functional (ADF) program, Release 2002.02; (Vrije Universteit: Amsterdam, The Netherlands, 2002).

[29] S. V. Borisov, S. G. Kozlova, S. P. Gabuda, " $\left[\left(\mathrm{HgO}_{8}\right) \mathrm{O}_{6}\right]_{4}$ group in mercury oxohalides: Real structures and quantum-chemical calculation,” J. Struct. Chem., vol. 45, pp. 156-159, 2004.

[30] H. Schmidbaur, S. Hofreiter, M. Paul, "Synthesis of the gold analog of the elusive doubly protonated water molecule," Nature, vol. 377, pp. 503-504, 1995.

[31] H. Shan and P. R. Sharp, "Double oxygen atom centered rhodium-gold clusters," Angew. Chem. Int. Edition English, vol. 35, pp. 635-636, 1996.

[32] René Masse, Jean-Claude Guitel, André Durif, "Structure cristalline du monophosphate $\mathrm{AgHg}_{2} \mathrm{PO}_{4}$. Données cristallographiques sur $\mathrm{AgHg}_{2} \mathrm{AsO}_{4}$, , J. Solid State Chem., vol. 23, pp. 369-373, 1978.

[33] H. Sarp, D. Y. Pushcharovsky, E. J. MacLean, S. J. Teat, N. V. Zubkova, "Tillmannsite, $\left(\mathrm{Ag}_{3} \mathrm{Hg}\right)(\mathrm{V}, \mathrm{As}) \mathrm{O}_{4}$, a new mineral: its description and crystal structure," Eur. J. Miner., vol. 15, pp. 177-180, 2003.

[34] S. V. Borisov, S. A. Magarill, N. V. Pervukhina, "Covalent interactions in mercury oxohalides and their role in crystal structure fragmentation," J. Struct. Chem., vol. 44, pp. 1018-1025, 2003.

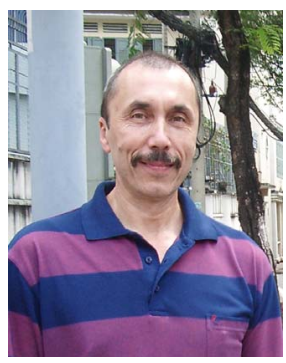

Victor V. Atuchin was born in Prokopievsk Russia on August, 1957. He received the diploma degree in radiophysics from the Tomsk State University, Tomsk/Russia in 1979 and the Ph.D. degree in solid state physics from the Institute of Semiconductor Physics of SB of RAS, Novosibirsk/Russia, in 1993. In 1980, he joined the Institute of Semiconductor Physics as an Engineer of Electronics, and as Head of Laboratory of Optical Materials and Structures in July 2002. Since 1980, his principal research interests have been in the fields of solid state physics, and materials science. His interests include fabrication and characterization of thin films, surface science and chemistry of oxide crystals. He is the author or coauthor of 189 publications in refereed journals.

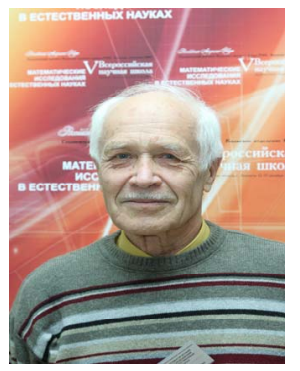

Stanislav V. Borisov was born in July 1930. He received her B.S. degree in physics and mathematics from Gorky State University (Gorky, USSR) in 1953, Ph.D. degree in crystallography and crystal physics from the Institute of Crystallography, RAS (Moscow, Russia) in 1964 and D.Sc. in crystallography and crystal physics from the Institute of Crystallography, RAS (Moscow, Russia) in 1974. Presently, he is working as Principal Research Scientist in Institute of Inorganic

Chemistry,SB RAS (Novosibirsk, Russia). Over many years, his research activities cover wide range of topics including crystallography, X-ray structural analysis, crystal properties, mineralogy and inorganic chemistry. He has published more than 200 refereed research articles in refereed journals and 5 monographs. Prof. Borisov is awarded by Fedorov's Prize of Russian Academy of Science and is a member of IUCr

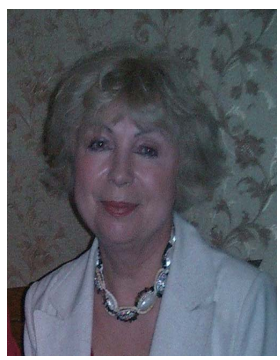

Svetlana A. Magarill was born in Biysk/Russia on September, 1946. She received the diploma of chemist from the Novosibirsk State University in 1969 and the Ph.D. degree in inorganic chemistry from the Institute of Inorganic Chemistry, SB of RAS, Novosibirsk, Russia, in 1974. In 1969, she joined the Institute of Inorganic Chemistry, an Siberian Branch (SB), Russian Academy of Sciences (RAS) Since 1974, her principal research interests were concerned with X-ray structure analysis and crystal chemistry of inorganic compounds. She is the author and coauthor of 150 publications in refereed journals.

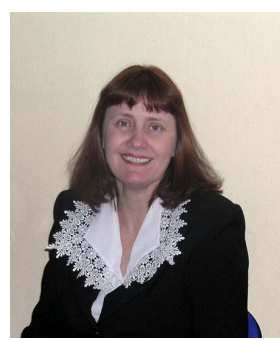

Natalia V. Pervukhina was born in Novokuznetsk/Russia on February, 1955. She received the diploma of chemist from the Novosibirsk State University in 1977 and the $\mathrm{Ph} . \mathrm{D}$. degree in inorganic chemistry from the Institute of Inorganic Chemistry, SB of RAS Novosibirsk, Russia, in 1990. In 1977, she joined the Institute of Inorganic Chemistry, an Siberian Branch (SB), Russian Academy of Sciences (RAS).

Since 1980, her principal research interests were concerned with X-ray structure analysis and crystal chemistry of inorganic and complex compounds. She is the author and coauthor of 200 publications in refereed journals. Prof. Pervukhina is a member of IUCr. 